\title{
L-carnitine and cancer cachexia. II. Effects of lipid emulsion used in total parenteral nutrition on parameters of hemostasis and inflammatory state in L-carnitine deficiency in myocytes
}

\author{
JAROSŁAW SZEFEL ${ }^{1}$, WIESŁAW JANUSZ KRUSZEWSKI ${ }^{1,2}$, MACIEJ CIESIELSKI ${ }^{1,2}$, \\ MARIUSZ SZAJEWSKI ${ }^{1,2}$, KRZYSZTOF KAWECKI ${ }^{1}$, JERZY JANKUN ${ }^{3,4}$ and WIESŁAWA ŁYSIAK-SZYDŁOWSKA ${ }^{5}$ \\ ${ }^{1}$ Department of Surgical Oncology, Gdynia Oncology Centre, PCK's Maritime Hospital, Gdynia; \\ ${ }^{2}$ Department of Propedeutics of Oncology, Faculty of Health Sciences, Medical University of Gdańsk, Gdańsk, Poland; \\ ${ }^{3}$ Urology Research Center, Department of Urology, The University of Toledo, Health Science Campus, \\ Toledo, OH 43614, USA; ${ }^{4}$ Department of Biochemistry, College of Sciences, King Saud University, Riyadh, \\ Saudi Arabia; ${ }^{5}$ Faculty of Health Sciences, Powiślański College of Kwidzyń, Kwidzyń, Poland
}

Received March 5, 2012; Accepted April 18, 2012

DOI: $10.3892 /$ or.2012.1805

\begin{abstract}
Cancer cachexia (CC), a progressive loss of body mass, leads to malnutrition and deficiencies of essential substances including polyunsaturated fatty acids (PUFAs) and L-carnitine (LC). The availability of these 2 compounds determines the rate of eicosanoid synthesis, which modulates inflammatory processes and hemostasis. We compared the effects of administration of emulsions containing long chain triglycerides (LCTs) relative to a 50:50 mix of medium chain triglycerides (MCTs) with LCTs on hemostasis and inflammatory reactions in patients with $\mathrm{CC}$. The study was conducted on 50 patients with CC ( 23 women, 27 men) aged $66 \pm 11$ years with a mean loss in body weight of $21 \pm 9 \%$ in the previous 6 months. Twenty patients received MCTs/LCTs while 30 received LCTs. Total parenteral nutrition (TPN) was administered using the 'all in one' method $(25 \mathrm{kcal} / \mathrm{kg} / \mathrm{day}$, protein $1.2 \mathrm{~g} / \mathrm{kg} /$ day). Selected parameters of coagulation and inflammatory state were evaluated on Days 1, 5, 7 and 11 of TPN. Initial concentrations of D-dimers, fibrinogen, plasminogen activator inhibitor type 1 (PAI-1), fibronectin, CRP and IL-6 significantly exceeded the upper limit of the reference values. After 10 days of TPN, we detected significant differences in inflammatory state and hemostasis. Immunological state and hemostasis varied depending on the type of fat emulsion
\end{abstract}

Correspondence to: Dr Jarosław Szefel, The PCK's Maritime Hospital, Gdynia Oncology Centre, Department of Surgical Oncology, Powstania Styczniowego 1, 81-587 Gdynia, Poland E-mail: jaszefel@mp.pl

Dr Jerzy Jankun, Urology Research Center, Department of Urology, The University of Toledo, Health Science Campus, 3000 Arlington Ave, Toledo, OH 43614, USA

E-mail: jerzy.jankun@utoledo.edu

Key words: cancer cachexia, fatty acids, total parenteral nutrition administered. The most likely reasons are the 2-fold higher concentrations of PUFAs in LCTs relative to MCTs/LCTs and a deficiency of LC in skeletal muscles. Both of these factors may contribute to the observed increase in the rate of eicosanoid synthesis.

\section{Introduction}

$\mathrm{CC}$ occurs as a result of many malignant cancers and is believed to contribute to up to a third of all cancer-related deaths. It is characterized by the loss of lean body mass (1). Loss of body fat can, but need not, necessarily accompany CC. The loss of lean body mass stems primarily from the highly selective degradation of skeletal muscle proteins and specifically targets the myosin heavy chain (2). Cytokines and tumor factors such as TNF- $\alpha$, IL- $1 \beta$, IL- 6 and IFN- $\gamma$ are known to mediate this process $(3,4)$.

Factors produced by cancer tissue modulate many signaling pathways, and alter expression of genes and proteins by regulating transcription, translation and post-translational modification (5). Their actions lead to a worsening of malnutrition and deficits of indispensable chemicals and nutrients, including polyunsaturated fatty acids (PUFAs) and L-carnitine (LC).

Many cancer patients with $\mathrm{CC}$ are unable to meet their nutritional and caloric needs via the gastrointestinal (GI) route. Therefore, as a part of oncological treatment, they are administered total parenteral nutrition (TPN). It is widely known that fat emulsions are not only an important source of energy generated from fats, but also essential PUFAs and fat-soluble vitamins.

A lipid emulsion that is still widely used in TPN is obtained from soybean oil. Its disadvantage is its high content of n-6 PUFAs (mainly arachidonic acid) which are known to increase inflammatory responses and the risk of thromboembolic complications $(6,7)$.

For this reason, new fat emulsions made of LCT and MCT, olive oil (n-9), and fish oil (n-3) (8,9) have been developed and 
introduced for use in TPN. This has introduced the possibility of modulating the relative proportions of n-6:n-3 PUFAs according to the needs of individual patients (10). Fat emulsions derived from soybeans contain up to 60-65\% PUFAs, including $52-54 \%$ of linoleic acid. The recommended dietary PUFA ratio of $n-6: n-3$ is $3: 1$, while the ratio in soybean oil is $7: 1(11,12)$. Fat emulsions containing a mix of MCT/LCT in the ratio 50:50 contains two times less PUFAs than LCT emulsion alone; therefore, it contains approximately $50 \%$ fewer substrates for the synthesis of pro-inflammatory eicosanoids (13).

This study was conducted to compare MCT/LCT mix vs. LCT emulsion in patients with $\mathrm{CC}$, and to assess their effects on inflammatory processes and hemostasis.

In Part I of this study (14), we showed that patients with CC have significant shortages of LC in their skeletal muscles. Thus, LC deficiency is likely to be an additional factor that affects hemostasis and the immune system regardless of the type of fat emulsion used.

\section{Materials and methods}

This study was conducted on a group of 50 patients (23 female, 27 male, mean age $65.8 \pm 10.6$ years). Loss of body weight averaged $21 \pm 9 \%$ for the 6 months prior to the study. Diagnosis of $\mathrm{CC}$ and inability to meet caloric and protein requirements via the GI tract were the criteria for inclusion. As a criterion of CC we assumed an unintentional loss of body weight in excess of $5 \%$ during the 6 months prior, related to the presence of cancer confirmed in histopathology. Cancer of the GI tract accounted for $78 \%$ of all cases. Patients with illnesses not associated with $\mathrm{CC}$, or in which, due to earlier oncological therapy (e.g. chemotherapy, radiotherapy, renal or hepatic failure), could cause changes in the parameters being studied were excluded. Blood was collected for testing at 8 a.m. on Days 1 (test 1), 5 (test 2), 7 (test 3) and 11 (test 4) day of hospital stay. The initial test was conducted before TPN was started.

The concentration of plasminogen activator inhibitor type 1 (PAI-1) was measured with Human PAI-1 ELISA kits from Bender MedSystems (Vienna, Austria). Serum levels of interleukin-6 (IL-6) were measured using kits from Bender MedSystems. FN Fibronectin (FN) in serum was measured using enzyme-linked immunosorbent assays (ELISA) with BMS2028 kits from Bender MedSystems. Quantitative determination of fibrinogen has been measured using Clauss method by Fibrinogen-C ${ }^{\circledR}$ kit manufactured by IL. Activated partial thromboplastin clotting time (aPTT) was measured using HemosIL ${ }^{\mathrm{TM}}$ APTT-SP from IL, prothrombin time (PT) using HemosIL ${ }^{\mathrm{TM}}$ RecombiPlasTin $2 \mathrm{G}$ from IL. Concentration of D-dimers was determined using HemosIL ${ }^{\circledR}$ D-dimer HS 500 on the ACL TOP family Systems. Measured values were compared to reference values provided by the manufacturers.

Based on measurements of height and body mass on the first day (i.e. before the start of TPN) BMI was calculated and patients were assigned to 2 groups based on their nutritional status, with BMI $\leq 19 \mathrm{~kg} / \mathrm{m}^{2}$ and BMI $>19 \mathrm{~kg} / \mathrm{m}^{2}$.

The distribution of age and gender in both groups were comparable. In order to assess the effects of the type of fat emulsions used on our test parameters, patients were divided into 2 further groups, i.e. those receiving a 50:50 mix of MCT/
LCT emulsion and those receiving pure LCT. There were no statistically significant differences as to age, gender and BMI between these 2 groups.

Ethics. Prior to recruiting patients for this study, we obtained approval from the Independent Bioethics Committee for Scientific Research at Medical University of Gdansk NKEBN/145/2008. All patients included in the study were informed properly about the issues concerning the study and they completed the necessary consent form.

Statistical analysis. Decision-making statistical analysis consisted of testing means using Student's t-test and the comparison of distributions (medians) using the non-parametric $U$ test with a special regard to the independence or dependence of variables in both of these tests.

Testing was performed in multi-way contingency tables using exact Fisher's test or Pearson $\chi^{2}$ test. The dependence measure was Pearson's correlation coefficient for which the Vanish test has been performed. Calculations were performed using the statistical package Statistica 9.0 and statistical computing environment R 2.12.0. A P-value $<0.05$ was recognized as statistically significant.

\section{Results}

Influence of CC on hemostasis and inflammatory reactions. On admission to hospital (i.e. before TPN administration), the values of activated partial thromboplastin time APTT were below the lower limits of reference values more often in $\mathrm{BMI} \leq 19 \mathrm{~kg} / \mathrm{m}^{2}$ group than in $\mathrm{BMI}>19 \mathrm{~kg} / \mathrm{m}^{2}$ group $(\mathrm{P}<0.024)$. Decreased antithrombin (AT) AT activity was observed more often in BMI $>19 \mathrm{~kg} / \mathrm{m}^{2}$ group than in BMI $\leq 19 \mathrm{~kg} / \mathrm{m}^{2}$ group $(\mathrm{P}<0.015)$. However, median AT was lower in BMI $>19 \mathrm{~kg} /$ $\mathrm{m}^{2}$ group relative to the $\mathrm{BMI} \leq 19 \mathrm{~kg} / \mathrm{m}^{2}$ group $(\mathrm{P}<0.008)$. Concentrations of PAI-1 were significantly above the upper limit of reference values in both groups $(\mathrm{P}<0.001$ in both). Concentrations of fibrinogen, $\mathrm{D}$-dimers and $\mathrm{C}$-reactive protein (CRP) were also above the upper limit of reference values in all patients.

The mean concentration of CRP in the BMI $\leq 19 \mathrm{~kg} / \mathrm{m}^{2}$ group was above the upper limit more frequently than in the BMI $>19 \mathrm{~kg} / \mathrm{m}^{2}$ group $(\mathrm{P}<0.05)$. The mean concentrations of IL- 6 in serum were higher than reference values in both the $\mathrm{BMI} \leq 19 \mathrm{~kg} / \mathrm{m}^{2}(\mathrm{P}<0.001)$ and $\mathrm{BMI}>19 \mathrm{~kg} / \mathrm{m}^{2}$ groups $(\mathrm{P}<0.003)$ (Table I).

Influence of MCT/LCT and LCT emulsions on hemostasis and inflammatory parameters. All measurements within the MCT/LCT and LCT groups were made between tests 1 and 4, i.e. Days 1 and 11 of hospital stay. Administration of MCT/ LCT emulsion $(\mathrm{P}<0.047)$ and LCT $(\mathrm{P}<0.030)$ was accompanied by a decrease in the number of blood platelets. There was no significant difference in the decrease between MCT/LCT and LCT groups (Table II).

APTT decreased in the group receiving MCT/LCT emulsion $(\mathrm{P}<0.052)$, while there was no significant difference in the LCT group. We found a significant increase in fibrinogen concentrations in the group receiving MCT/LCT emulsion $(\mathrm{P}<0.015)$ (Table II). AT activity decreased significantly 
Table I. Comparison of selected coagulation and immunological parameters to reference values.

\begin{tabular}{|c|c|c|c|c|}
\hline & $\mathrm{BMI}\left(\mathrm{kg} / \mathrm{m}^{2}\right)$ & $\begin{array}{c}\text { Compared to reference } \\
\text { values ( } \% \text { patients) }\end{array}$ & Mean \pm SEM & $\begin{array}{c}\text { Range of } \\
\text { reference values }\end{array}$ \\
\hline Platelets $\left(10^{3} / \mu 1\right)$ & $\begin{array}{l}\mathrm{BMI} \leq 19 \\
\mathrm{BMI}>19\end{array}$ & $\begin{array}{l}\text { Normal in } 52 \\
\text { Normal in } 56\end{array}$ & $\begin{array}{l}354 \pm 156 \\
338 \pm 162\end{array}$ & $155-366$ \\
\hline IL-6 (pg/ml) & $\begin{array}{l}\mathrm{BMI} \leq 19 \\
\mathrm{BMI}>19\end{array}$ & $\begin{array}{l}\text { Higher in } 52 \\
\text { Higher in } 58\end{array}$ & $\begin{array}{l}23.9 \pm 23.9 \\
61.8 \pm 87.8\end{array}$ & $1.4-14.1$ \\
\hline PAI-1 (ng/ml) & $\begin{array}{l}\mathrm{BMI} \leq 19 \\
\mathrm{BMI}>19\end{array}$ & $\begin{array}{l}\text { Higher in } 73 \\
\text { Higher in } 75\end{array}$ & $\begin{array}{l}343.7 \pm 149.3 \\
405.9 \pm 198.3\end{array}$ & $1.2-286$ \\
\hline $\mathrm{CRP}^{\mathrm{a}}(\mathrm{mg} / \mathrm{l})$ & $\begin{array}{l}\mathrm{BMI} \leq 19 \\
\mathrm{BMI}>19\end{array}$ & $\begin{array}{l}\text { Higher in } 100 \\
\text { Higher in } 81\end{array}$ & $\begin{array}{l}35.8 \pm 29.7 \\
60.5 \pm 79.4\end{array}$ & $0.0-5.0$ \\
\hline $\operatorname{APTT}^{\mathrm{a}}(\mathrm{s})$ & $\begin{array}{l}\mathrm{BMI} \leq 19 \\
\mathrm{BMI}>19\end{array}$ & $\begin{array}{l}\text { Normal in } 77 \\
\text { Normal in } 93\end{array}$ & $\begin{array}{c}32.8 \pm 15.6 \\
30.4 \pm 3.4\end{array}$ & $25.0-37.0$ \\
\hline Fibrinogen $(\mathrm{g} / \mathrm{l})$ & $\begin{array}{l}\mathrm{BMI} \leq 19 \\
\mathrm{BMI}>19\end{array}$ & $\begin{array}{l}\text { Higher in } 82 \\
\text { Higher in } 70\end{array}$ & $\begin{array}{l}5.2 \pm 1.4 \\
4.9 \pm 1.6\end{array}$ & $2.0-4.7$ \\
\hline $\mathrm{AT}^{\mathrm{a}}(\%)$ & $\begin{array}{l}\mathrm{BMI} \leq 19 \\
\mathrm{BMI}>19\end{array}$ & $\begin{array}{l}\text { Normal in } 86 \\
\text { Normal in } 58\end{array}$ & $\begin{array}{l}105 \pm 15 \\
92 \pm 18\end{array}$ & $80-120$ \\
\hline D-dimer $(\mu \mathrm{g} / \mathrm{l})$ & $\begin{array}{l}\mathrm{BMI} \leq 19 \\
\mathrm{BMI}>19\end{array}$ & $\begin{array}{l}\text { Higher in } 90 \\
\text { Higher in } 85\end{array}$ & $\begin{array}{l}2505 \pm 2941 \\
2898 \pm 2766\end{array}$ & $0-500$ \\
\hline INR & $\begin{array}{l}\mathrm{BMI} \leq 19 \\
\mathrm{BMI}>19\end{array}$ & $\begin{array}{l}\text { Normal in } 91 \\
\text { Normal in } 81\end{array}$ & $\begin{array}{l}1.1 \pm 0.4 \\
1.1 \pm 0.1\end{array}$ & $0.9-1.3$ \\
\hline
\end{tabular}

${ }^{\mathrm{a}} \mathrm{P}<0.05$ for BMI $>19 \mathrm{~kg} / \mathrm{m}^{2}$ vs. BM I<19 kg/m². IL-6, interleukin-6; PAI-1, plasminogen activator inhibitor; CRP, C-reactive protein; APTT, activated partial thromboplastin time; AT-III, antithrombin; INR, international normalized ratio.

Table II. Changes in immunological and hemostatic parameters in relation to fat emulsion type.

\begin{tabular}{|c|c|c|c|c|}
\hline & \multicolumn{2}{|c|}{$\mathrm{MCT} / \mathrm{LCT}$} & \multicolumn{2}{|c|}{ LCT } \\
\hline & Test 1 & Test 4 & Test 1 & Test 4 \\
\hline Fibronectin $(\mu \mathrm{g} / \mathrm{ml})$ & $319 \pm 97$ & $355 \pm 39$ & $350 \pm 76$ & $373 \pm 19$ \\
\hline $\mathrm{CRP}^{\mathrm{a}}(\mathrm{mg} / \mathrm{l})$ & $33 \pm 41$ & $89 \pm 50^{b}$ & $60 \pm 72$ & $90 \pm 77^{c}$ \\
\hline Lymphocytes $\left(10^{3} / \mathrm{ml}\right)$ & $1.10 \pm 0.63$ & $1.14 \pm 0.50$ & $1.26 \pm 0.65$ & $1.29 \pm 0.77$ \\
\hline Leukocytes $\left(10^{3} / \mathrm{ml}\right)$ & $9.22 \pm 5.67$ & $9.59 \pm 4.07$ & $9.02 \pm 5.10$ & $9.37 \pm 4.41$ \\
\hline IL-6 (pg/ml) & $30.1 \pm 31.8$ & $68.0 \pm 90.0$ & $54.0 \pm 85.0$ & $89.0 \pm 107.0$ \\
\hline PAI-1 (ng/ml) & $381 \pm 174$ & $375 \pm 158$ & $373 \pm 183$ & $316 \pm 201^{c}$ \\
\hline Fibrinogen $(\mathrm{g} / \mathrm{l})$ & $4.6 \pm 1.2$ & $5.3 \pm 1.3^{\mathrm{b}}$ & $5.4 \pm 1.6$ & $6.0 \pm 1.5$ \\
\hline $\mathrm{AT}^{\mathrm{a}}(\%)$ & $89 \pm 17$ & $103 \pm 17$ & $103 \pm 17$ & $93 \pm 17^{c}$ \\
\hline INR & $1.1 \pm 0.1$ & $1.1 \pm 0.1$ & $1.2 \pm 0.3$ & $1.1 \pm 0.2$ \\
\hline APTT (s) & $33 \pm 16$ & $32 \pm 6^{\mathrm{b}}$ & $30 \pm 4$ & $32 \pm 7$ \\
\hline D-dimer $(\mu \mathrm{g} / \mathrm{l})$ & $1749 \pm 1475$ & $2408 \pm 1215^{\mathrm{b}}$ & $3383 \pm 3315$ & $5003 \pm 3436$ \\
\hline Platelets $\left(10^{3} / \mathrm{ml}\right)$ & $313 \pm 106$ & $268 \pm 86^{\mathrm{b}}$ & $360 \pm 181$ & $284 \pm 93^{c}$ \\
\hline
\end{tabular}

${ }^{\mathrm{a}} \mathrm{P}<0.05$ comparison of changes in the MCT/LCT relative to the LCT group between test 1 and test $4 .{ }^{\mathrm{b}} \mathrm{P}<0.05$ change in concentrations between test 1 and test 4 in the MCT/LCT group $4 .{ }^{\mathrm{c}} \mathrm{P}<0.05$ change in concentrations between test 1 and test 4 in the LCT group 4 .

between tests 1 and 4 in the group receiving LCT emulsion $(\mathrm{P}<0.009)$. This decrease in AT activity was significantly higher under the influence of LCT relative to MCT/LCT emulsion $(\mathrm{P}<0.037)$ (Table II).
Concentrations of PAI-1 were significantly lower in patients receiving LCT emulsion $(\mathrm{P}<0.037)$ (Table II) while D-dimer concentrations were significantly higher in patients receiving MCT/LCT $(\mathrm{P}<0.004)$. 
Levels of CRP increased in both the MCT/LCT $(\mathrm{p}<0.004)$ and LCT $(\mathrm{P}<0.025)$ groups between tests 1 and 4 , i.e. days 1 and 11 of hospital stay. This increase was significantly higher in the former group $(\mathrm{P}<0.042)$.

\section{Discussion}

Numerous studies have shown that CC is accompanied by an increased expression of inflammatory markers and a tendency towards hypercoagulability, likely in response to various factors released by cancerous tissue (15). Secondary components of many signaling pathways are responsible for regulation of these inflammatory reactions, including lipid derivatives such as the phospholipid activator platelet-activating factor (PAF) and eicosanoids such as prostaglandins, prostacyclins, thromboxanes, leukotrienes and many others (16). Thus, the amounts of PUFAs delivered in TPN determines the amounts and type of synthesized eicosanoid derivatives, which in turn determines the level of activity of the immune system and hemostatic pathway (17).

LC has been shown to reduce the levels of markers of systemic inflammation and inflammation-related coagulation factors. We believe that the recently discovered group of enzymes belonging to the acyltransferase family brings us closer to understanding this phenomenon (18). The concentration of LC and activity of carnitine palmitoyltransferase I (CPT-1) determines the ratio of AC/acylCoA (acyl-carnitine-AC) and on that, depends the availability of PUFA as a substrate for acyl-CoA:lysophospholipid acyltransferase (19).

This group of enzymes catalyzes the binding of PUFAs to the free position of sn-2 of lisophospholipids $(20,21)$. In the next step, phospholipids are removed from PUFAs by phospholipase A2 and converted to eicosanoids by cyclooxygenase (COX) and lipoxygenase (LOX).

LC forms $\mathrm{AC}$ and free $\mathrm{CoA}$ by binding acyl groups of acyl-CoA. As a result, there is a decline in the concentration of acyl-CoA and a reduction in the acylation rate of lysophopholipids (22). Alteration in the composition of phospholipid membranes is a result of consecutive reactions of deacylation and acylation, which leads to an asymmetric distribution of phospholipids in both layers of cell membranes (23).

In part I of this study (14), a deficiency in LC was found in the skeletal muscles of patients with CC. Muscle degradation is considered to be the main cause, along with dietary restrictions and a decrease in endogenous LC synthesis. There are reasons to suspect that LC may also be deficient in the lymphatic system. Adlouni et al (24) and Katrib et al (25) have conducted a series of experiments confirming the adverse effects of LC deficiency on immune system functions. LC concentrations rise in granulocytes in response to acute bacterial infections, and also in lymphocytes as a result of chronic inflammatory processes (26). LC deficiency in lymphoid tissues can disrupt immune system responses to infectious elements. Indeed, studies show the beneficial influence of LC supplementation on immune system functions $(27,28)$.

This study showed a significant increase in the concentration of fibrinogen $(\mathrm{P}<0.015)$ after 11 days of MCT/LCT administration, with no measurable changes in the LCT group. Fibrinogen is an acute phase protein that plays an important role in blood coagulation. An increase in its concentration indirectly reflects both an increased risk of excessive blood clotting and an increased intensity of the host inflammatory response.

The main stimulus for synthesis of fibrinogen is IL-6 $(29,30)$. In our study initial IL-6 concentrations are much higher than the upper limit of the range of reference values in all patients (Table I). Further, its levels did not change substantially in patients receiving either MCT/LCT or LCT (Table II). Increased fibrinogen synthesis in patients receiving MCT/ LCT could result from better $\beta$-oxidation efficiency relative to those receiving LCT only, due to L-carnitine deficiency. Our study also showed an increase of D-dimer levels in patients receiving MCT/LCT $(\mathrm{P}<0.004)$. D-dimers are known products of fibrin degradation. We observed no such increase in patients receiving LCT. Therefore, increased fibrinogen levels in patients receiving MCT/LCT are likely a result of faster synthesis relative to degradation rate.

Factors that affect fibrinogen synthesis include sufficient stimulus, substrate availability and adequate energy inflow. However, changes in fibrinogen levels depend on the synthesis/ degradation ratio. The main stimulus for fibrinogen synthesis is IL-6 and amino acids are essential substrates for that reaction $(29,30)$. Our study showed that even though the initial IL-6 level (test 1) in all patients significantly exceeded the upper reference value, it did not change substantially during MCT/LCT or LCT dosage (Table II). The amounts of amino acids administered in both groups during TPN were directly proportional to patient body mass.

Between tests 1 and 4, we found a statistically significant decrease in AT activity in the group receiving LCT $(\mathrm{P}<0.009)$. This decrease was significantly greater relative to that in patients receiving MCT/LCT $(\mathrm{P}<0.037)$, in whom AT activity did not change significantly (Table II). Average AT activity on both days was still within the range of reference values. AT is a strong serine protease inhibitor that inactivates thrombin and the clotting factors XII, IX and X and also has anti-inflammatory properties resulting from its stimulation of prostacyclin synthesis $(31,32)$.

PAI-1 limits the activity of tissue plasminogen activator (tPA) and urokinase-type plasminogen activator (uPA), thereby lowering the conversion of plasminogen to plasmin. As a consequence, PAI-1 strongly inhibits fibrinolysis.

The average PAI- 1 concentration measured during test 1 was significantly above reference values. Patients receiving LCT showed a significant decrease in PAI-1 concentrations $(\mathrm{P}<0.037)$ (Table II). It is highly probable that this decrease resulted from a restriction of its synthesis due to less efficient $\beta$-oxidation of fatty acids due to lack of LC.

There were no substantial changes to the International Normalized Ratio INR between tests 1 and 4, either in the group receiving MCT/LCT emulsion or LCT (Table II). The study showed that APTT $(\mathrm{P}<0.052)$ in patients treated with MCT/LCT emulsion was reduced, although it did not change substantially in the LCT group (Table II).

INR and APTT are coagulation parameters of a global character. Lack of significant deviation from reference values in these 2 tests, despite changes in other coagulation parameters, shows that the balance between blood coagulation and fibrinolysis in the body is being maintained. 
We found a significant increase in CRP concentrations in patients receiving MCT/LCT $(\mathrm{P}<0.004)$ and LCT $(\mathrm{P}<0.025)$; this increase was significantly greater in the former group $(\mathrm{P}<0.042)$ (Table II). CRP protein is produced in the liver, and acts as an opsonin that activates the classical pathway of the complement system. In spite of its participation in the inflammatory response, CRP has hypercoagulable properties $(33,34)$. Its levels rise in response to increased concentrations of many cytokines that accompany a neoplasm, mainly IL-6. While an increase in CRP concentrations is a reliable marker of host inflammatory state, it also demonstrates the capacity of host defensive mechanisms. The most likely cause of increased CRP levels in both experimental groups is increased synthesis from amino acid substrates in TPN.

MCT does not require LC for transport across the inner mitochondrial membrane. In conditions in which LC is deficient, MCT is a better source of energy than LCT. Therefore, it is likely that the higher energy efficiency of MCT/LCT resulted in a significantly greater increase in CRP concentrations in the $\mathrm{MCT} / \mathrm{LCT}$ group relative to the LCT group. Less involvement of LC by MCT/LCT favors an increase in the concentration of free carnitine (FC), so buffering of acyl-CoA by FC is also more effective in the MCT/LCT group. This favors a higher rate of eicosanoid synthesis. This means that the ratio of PUFA n-6:n-3 is close to 7:1 both in the MCT/LCT (50:50) and LCT groups as synthesis of their pro-inflammatory derivatives dominates in both. The only difference is that in the MCT/ LCT group the PUFA content is probably two times lower than in the LCT group.

Immunological state and hemostasis varies in patients with CC depending on the type of fat emulsion used in TPN. Most likely the main causes of these differences are: twice the quantity of PUFAs in LCT relative to MCT/LCT and LC deficiency in skeletal muscles. Both of these factors contribute to an increased rate of synthesis of eicosanoids. Another reason for the differences seen in this study may be the lower energy efficiency of $\beta$-oxidation of LCT relative to MCT/LCT under conditions of LC deficiency in skeletal muscles.

\section{Acknowledgements}

This study was supported by the Fundacja na Rzecz Rozwoju Chirurgii 'Viribus Unitis' im. Profesora Jankaua. Fundacja pożytku publicznego, Gdynia.

\section{References}

1. Fearon K, Strasser F, Anker SD, et al: Definition and classification of cancer cachexia: an international consensus. Lancet Oncol 12: 489-495, 2011.

2. Acharyya S, Ladner KJ, Nelsen LL, et al: Cancer cachexia is regulated by selective targeting of skeletal muscle gene products. J Clin Invest 114: 370-378, 2004

3. Karayiannakis AJ, Syrigos KN, Polychronidis A, Pitiakoudis M, Bounovas A and Simopoulos K: Serum levels of tumor necrosis factor-alpha and nutritional status in pancreatic cancer patients. Anticancer Res 21: 1355-1358, 2001.

4. Gelin J, Moldawer LL, Lonnroth C, Sherry B, Chizzonite R and Lundholm K: Role of endogenous tumor necrosis factor alpha and interleukin 1 for experimental tumor growth and the development of cancer cachexia. Cancer Res 51: 415-421, 1991.

5. Duplus E and Forest C: Is there a single mechanism for fatty acid regulation of gene transcription? Biochem Pharmacol 64: 893-901, 2002.
6. Pignatelli P, Lenti L, Sanguigni V, et al: Carnitine inhibits arachidonic acid turnover, platelet function, and oxidative stress. Am J Physiol Heart Circ Physiol 284: H41-H48, 2003.

7. Szefel J, Piotrowska M, Kruszewski WJ, Jankun J, LysiakSzydlowska W and Skrzypczak-Jankun E: Eicosanoids in prevention and management of diseases. Curr Mol Med 11: 13-25, 2011.

8. Carpentier YA and Dupont IE: Advances in intravenous lipid emulsions. World J Surg 24: 1493-1497, 2000.

9. Escrich E, Solanas M, Moral R and Escrich R: Modulatory effects and molecular mechanisms of olive oil and other dietary lipids in breast cancer. Curr Pharm Des 17: 813-830, 2011.

10. Calder PC, Jensen GL, Koletzko BV, Singer P and Wanten GJ: Lipid emulsions in parenteral nutrition of intensive care patients: current thinking and future directions. Intensive Care Med 36: 735-749, 2010.

11. Wanten GJ and Calder PC: Immune modulation by parenteral lipid emulsions. Am J Clin Nutr 85: 1171-1184, 2007.

12. Simopoulos AP: The importance of the ratio of omega-6/ omega-3 essential fatty acids. Biomed Pharmacother 56: 365-379, 2002.

13. Pradier O, Portois L, Malaisse WJ and Carpentier YA: Hemostatic safety of the bolus intravenous injection of a novel medium-chain triglyceride: fish oil emulsion. Int J Mol Med 22: 301-307, 2008.

14. Szefel J, Kruszewski WJ, Ciesielski M, Szajewski M, Kawecki K, Aleksandrowicz-Wrona E, Jankun J and LysiakSzydlowska W: L-carnitine and cancer cachexia. I. L-carnitine distribution and metabolic disorders in cancer cachexia. Oncol Rep 28: 319-323, 2012.

15. dos Santos Silva I, De Stavola BL, Pizzi C and Meade TW: Circulating levels of coagulation and inflammation markers and cancer risks: individual participant analysis of data from three long-term cohorts. Int J Epidemiol 39: 699-709, 2010.

16. Wang D and Dubois RN: Eicosanoids and cancer. Nat Rev Cancer 10: 181-193, 2010.

17. Heller AR, Fischer S, Rossel T, et al: Impact of n-3 fatty acid supplemented parenteral nutrition on haemostasis patterns after major abdominal surgery. Br J Nutr 87 (Suppl 1): S95-S101, 2002.

18. Yamashita A, Nakanishi H, Suzuki H, et al: Topology of acyltransferase motifs and substrate specificity and accessibility in 1-acyl-sn-glycero-3-phosphate acyltransferase 1. Biochim Biophys Acta 1771: 1202-1215, 2007.

19. Kazachkov M, Chen Q, Wang L and Zou J: Substrate preferences of a lysophosphatidylcholine acyltransferase highlight its role in phospholipid remodeling. Lipids 43: 895-902, 2008.

20. Prasad SS, Garg A and Agarwal AK: Enzymatic activities of the human AGPAT isoform 3 and isoform 5: localization of AGPAT5 to mitochondria. J Lipid Res 52: 451-462, 2011.

21. Hollenback D, Bonham L, Law L, et al: Substrate specificity of lysophosphatidic acid acyltransferase beta - evidence from membrane and whole cell assays. J Lipid Res 47: 593-604, 2006.

22. Arduini A, Bressan M, Sciarroni F, Dottori S, Calvani M and Ramsay RR: Carnitine palmitoyltransferase and acyl-coA binding protein: two more players in the membrane phospholipid fatty acid turnover of human red cells? Biochem J 325: 811-814, 1997.

23. Yamashita A, Sugiura T and Waku K: Acyltransferases and transacylases involved in fatty acid remodeling of phospholipids and metabolism of bioactive lipids in mammalian cells. J Biochem 122: 1-16, 1997.

24. Adlouni HA, Katrib K and Ferard G: Changes in carnitine in polymorphonuclear leukocytes, mononuclear cells, and plasma from patients with inflammatory disorders. Clin Chem 34: 40-43, 1988.

25. Katrib K, Adlouni AH and Ferard G: Carnitine in human polymorphonuclear leukocytes, mononuclear cells, and platelets. Am J Clin Nutr 46: 734-735, 1987.

26. Demirkol M, Sewell AC and Bohles $\mathrm{H}$ : The variation of carnitine content in human blood cells during disease - a study in bacterial infection and inflammatory bowel disease. Eur J Pediatr 153: 565-568, 1994.

27. Izgut-Uysal VN, Agac A, Karadogan I and Derin N: Effects of L-carnitine on neutrophil functions in aged rats. Mech Ageing Dev 124: 341-347, 2003.

28. Cress AP, Fraker PJ and Bieber LL: Carnitine and acylcarnitine levels of human peripheral blood lymphocytes and mononuclear phagocytes. Biochim Biophys Acta 992: 135-139, 1989. 
29. Amrani DL: Regulation of fibrinogen biosynthesis: glucocorticoid and interleukin-6 control. Blood Coagul Fibrinolysis 1: 443-446, 1990.

30. Vasse M, Paysant J, Soria J, Collet JP, Vannier JP and Soria C: Regulation of fibrinogen biosynthesis by cytokines, consequences on the vascular risk. Haemostasis 26 (Suppl 4): 331-339, 1996.

31. Oelschlager C, Romisch J, Staubitz A, et al: Antithrombin III inhibits nuclear factor kappaB activation in human monocytes and vascular endothelial cells. Blood 99: 4015-4020, 2002.

32. Horie S, Ishii H and Kazama M: Heparin-like glycosaminoglycan is a receptor for antithrombin III-dependent but not for thrombindependent prostacyclin production in human endothelial cells. Thromb Res 59: 895-904, 1990.
33. Chi M, Tridandapani S, Zhong W, Coggeshall KM and Mortensen RF: C-reactive protein induces signaling through $\mathrm{Fc}$ gamma RIIa on HL-60 granulocytes. J Immunol 168: 1413-1418, 2002.

34. Filep JG, Herman F, Kelemen E and Foldes-Filep E: C-reactive protein inhibits binding of platelet-activating factor to human platelets. Thromb Res 61: 411-421, 1991. 